\title{
BILIRUBIN-PROTEIN LINKAGES IN SERUM AND THEIR RELATIONSHIP TO THE VAN DEN BERGH REACTION 1
}

\author{
BY GERALD KLATSKIN AND LUITGARD BUNGARDS 2
}

\author{
(From the Department of Internal Medicine, Yale University School of Medicine, \\ New Haven, Conn.)
}

(Submitted for publication October 26, 1955; accepted January 16, 1956)

Innumerable theories have been advanced to explain the direct and indirect van den Bergh reactions of serum bilirubin. However, only three are still current. These postulate that the two types of diazotization are dependent on (a) differences in the chemical structure of bilirubin, (b) the presence of a catalyst that facilitates diazotization in the absence of alcohol, or (c) differences in the linkage of bilirubin to protein.

The theory that the variable behavior of bilirubin is in some way related to the nature of its linkage with protein has always had the greatest number of proponents, and has had an important influence in the formulation of current concepts of regurgitation and retention jaundice $(1,2)$. As originally conceived (3) indirect-reacting bilirubin was assumed to be a protein complex which was split as it passed through the liver cells, so that the direct-reacting pigment in bile and that found in the serum under certain conditions was thought to be present in an unbound state. However, it is now known from studies based on dialysis (4), ultra-filtration $(5,6)$, ultracentrifugation (7), and electrophoresis (6-8), that both types of pigment are linked to protein. This has led to several revisions of the theory. Accordingly, it has been suggested that, while both types of bilirubin are bound to albumin, the complex is dissociable in the case of direct-reacting serum, and stable, possibly because of a valence bond, in the case of the indirect-reacting type (6). As an alternative, it has been proposed that the two types of pigment are linked to different proteins, the direct-reacting type being bound to albumin and the indirect to globin $(9,10)$ or to an

\footnotetext{
1 Supported by a grant from the Ames Company, Inc., Elkhart, Indiana.

2 Formerly James Hudson Brown Memorial Fellow in Medicine, Yale University School of Medicine. Present address: Medizinische Universitäts-Klinik, Freiburg/ Breisgau, Germany.
}

alpha-globulin (11). Watson (1) has incorporated both ideas into what is, perhaps, the most widely accepted concept at the present time. According to this view indirect-reacting bilirubin is a stable globulin complex derived from hemoglobin. On passing through the liver cells bilirubin is split off and excreted into the bile as a sodium salt which yields the direct van den Bergh reaction. Under conditions leading to the regurgitation of bile into the blood, sodium bilirubinate is loosely bound by albumin, but continues to react directly. This theory is based on the assumption that: 1) in the breakdown of hemoglobin to bilirubin, globin remains firmly attached to the ruptured porphyrin nucleus until it traverses the liver cells, 2) the electrophoretic mobility of bilirubin-globin is identical with that of albumin, the fraction of serum in which most, if not all, the bilirubin is usually found $(7,8), 3)$ sodium bilirubinate reacts directly both in the presence and absence of albumin, and 4) the addition of alcohol in the indirect reaction facilitates diazotization by releasing bilirubin from its protein complex. Little direct evidence has been presented in support of this hypothesis, and, indeed, a number of observations appear to be inconsistent with it.

Early electrophoretic studies indicated that all the bilirubin in serum was bound to albumin (6). However, on fractionating the plasma proteins under special conditions Cohn (12) found that the alpha ${ }_{1}$-globulin concentrated in fraction V-1 contained a pigment which gave the indirect van den Bergh reaction. Later, Gray and Kekwick (8) confirmed the presence of bilirubin in alpha-globulin electrophoretically. However, they emphasized that the bulk of the pigment was always associated with albumin, and that the fraction bound to globulin was constant in amount and independent of the type of van den Bergh reaction. On the basis of ammonium sulfate fractionation 
studies, Najjar and Childs $(11,13)$ also reached the conclusion that a fraction of serum bilirubin was bound to globulin. However, in contrast to Cohn (12) and Gray and Kekwick (8), they suggested that all of the indirect-reacting pigment in serum was associated with a globulin, while all of the direct-reacting type was bound to albumin.

The present investigation was undertaken to re-evaluate the conflicting evidence pertaining to the protein-linkage of bilirubin in serum, and its relationship to the van den Bergh reaction. Filter-paper electrophoresis, which was the principal method employed, provided a convenient means of studying many of the problems involved. In particular it made it possible to characterize the properties of the pigments isolated from each of the protein fractions, and to compare them with those present in the original serum. Due consideration was given to the fact that all sera contain both direct- and indirect-reacting bilirubin, and that the qualitative van den Bergh reaction, used to identify the pigments in many similar investigations, merely distinguishes between low and high concentrations of direct-reacting pigment $(1,14)$.

\section{METHODS}

Serum samples. Blood was drawn from patients with various types of jaundice and allowed to coagulate at room temperature. Following centrifugation the supernatant serum was analyzed for its content of directreacting ("one-minute") and total bilirubin by a modification (14) of the Malloy-Evelyn method (15). The remaining serum was then stored at 5 to $10^{\circ} \mathrm{C}$ for 8 to 10 hours before being subjected to electrophoresis. In a few experiments serum was stored in the frozen state at $-20^{\circ} \mathrm{C}$ for periods up to several weeks. Preliminary investigation revealed that the electrophoretic mobilities of bilirubin and protein did not change during such storage. The total bilirubin concentration fell slightly, but there was no alteration in the ratio of the direct- and indirect-reacting fractions.

Electrophoresis. Electrophoretic analyses were carried out at room temperature by the filter-paper method described by Grassmann and Hannig (16). This entailed the use of (a) Whatman No. 1 filter-paper strips $(4 X$ $40 \mathrm{~cm}$.) stretched horizontally between buffer-filled electrode wells in a shallow, glass- and plastic-enclosed airchamber, ${ }^{3}$ (b) Michaelis' buffer (sodium veronal, sodium acetate and $\mathrm{HCl}$ ) with $\mathrm{a} \mathrm{pH}$ of 8.6 and ionic strength of 0.1 , and (c) a voltage of 110 for 14 to 16 hours yielding a current of approximately $1.0 \mathrm{~mA}$ through each of the strips. Three chambers, each containing a pair of strips, were usually run simultaneously.

${ }^{3}$ Obtained from Bender and Hobein, Munich, Germany.
One strip in each chamber was streaked with $0.10 \mathrm{ml}$. of serum and was used for the separation and identification of the pigment in each of the protein fractions. This was found to be the smallest volume which permitted accurate qualitative and quantitative analysis of the pigments. Unfortunately, resolution of the protein bands was not optimal, so that it was found desirable to run a control strip in each chamber streaked with $0.01 \mathrm{ml}$. of serum. This yielded sharply defined protein bands which facilitated identification of the peaks in the denser strip. It should be noted, however, that the mobilities of protein and pigment were always compared on the same strip, since their absolute mobilities on the two strips were not always identical. Better definition of the protein peaks could be achieved with large volumes of serum by using heavier filter-paper. However, eluates from such paper were invariably clouded by a fine pulp which could not be removed by filtration or centrifugation.

The electrophoretically separated protein fractions were stained and then quantitated either by direct densitometry or by spectrophotometry following elution. The pigments were studied in a similar manner, except that preliminary staining was omitted. Since it was essential to analyze the same strip for both protein and bilirubin it was not possible to use both the densitometric and elution methods in each instance. Therefore, each strip was subjected to one of two combined procedures : 1) direct densitometry of the pigment bands followed by staining and subsequent densitometry of the protein fractions, or 2) division of the strip into two longitudinal sections, measuring 8 and $32 \mathrm{~mm}$. in width, respectively, followed by staining and direct densitometry of the narrower strip for the localization of the protein bands, and elution of the unstained broader strip for bilirubin analysis. The former method permitted more accurate determination of the relative mobilities of the pigment and protein fractions, while the latter made it possible to establish the chemical nature of the pigments. Accordingly most experiments were carried out in duplicate using both combined procedures.

Staining of protein. Following air-drying and heat-fixation, the strips were stained with Amidoschwarz 10B and washed in acetic acid-methanol as recommended by Grassmann and Hannig (16).

Densitometry. The location and density of the pigment bands and the stained protein fractions were determined by scanning the strip at $1 \mathrm{~mm}$. intervals through a $25 \times 1$ $\mathrm{mm}$. slit in a Photovolt densitometer (Model 525). The recorded density readings were then plotted against the migration in millimeters and the points joined to form smooth curves. When the strip was split longitudinally, as described above, the narrow, stained protein strip was scanned at $1 \mathrm{~mm}$. intervals through a $6 \times 1 \mathrm{~mm}$. slit.

The protein-stained strips were cleared in alphabromnaphthalene and paraffin oil (16) before scanning, a procedure which decreased the density and permitted more accurate densitometry. This was omitted in the case of the unstained strips to be scanned for pigment.

It was found that the relationship between the areas of the peaks delineated by direct densitometry and the con- 
centration of protein in the individual fractions was not strictly linear, so that the patterns obtained did not provide an accurate estimate of relative concentrations. Nevertheless, this in no way detracted from the precision of the method in determining the relative mobilities of the protein and pigment fractions.

Determination of eluted bilirubin. Attempts to identify and quantitate bilirubin on filter paper by diazotization and direct densitometry were unsuccessful, since the color evolved was never typical of azobilirubin, and was usually of too low intensity to measure accurately. It was necessary, therefore, to devise a technique which permitted both quantitative analysis and study of the absorption spectrum of the small amounts of pigment present in the eluates of $5 \mathrm{~mm}$. filter-paper segments. This was accomplished by modifying the Malloy-Evelyn method (15) taking advantage of the greatly increased sensitivity afforded by the use of long pathway micro-cuvettes ( $50 \times$ $4 \mathrm{~mm}$.) in a Beckman DU spectrophotometer (17).

Each $5 \mathrm{~mm}$. segment of filter-paper was immersed in 2 $\mathrm{ml}$. of distilled water for one hour, following which the eluate was divided into two $1-\mathrm{ml}$. aliquots. To one was added $0.2 \mathrm{ml}$. of diazo blank and to the other $0.2 \mathrm{ml}$. of freshly prepared diazo reagent. The mixtures were agitated, transferred to micro-cuvettes and then read in the spectrophotometer at a wave length of $540 \mathrm{~m} \mu$ in precisely one minute. For the total bilirubin determination the contents of each cuvette were removed by pipette and returned to their original containers. To each of these was then added $1.2 \mathrm{ml}$. of absolute methanol with thorough mixing. At the end of one-half hour the cuvettes were refilled and read in the spectrophotometer as before.
To characterize further the nature of the pigments in each of filter-paper segments, the absorption spectrum of each eluate was studied both before and after diazotization.

\section{RESULTS}

\section{Direct densitometry of pigments in filter-paper electrophoretic patterns of icteric serum}

All strips showed a sharply defined yellow band which coincided precisely with the position of the albumin peak, irrespective of whether the bilirubin content of the original serum was predominantly of the direct- or indirect-reacting type. On the basis of its absorption spectrum and subsequent behavior on diazotization, the pigment eluted from this band was identified as bilirubin. A second inconstant pigment of a pale reddish-brown hue was occasionally observed in the region of the alpha and beta globulins. This gave a positive guaiac reaction, had the absorption spectrum of hemoglobin, and therefore, was interpreted as an artifact due to hemolysis. A typical pattern showing both bands and their relationship to the separated protein fractions of serum is illustrated in Figure 1A.

The pigment associated with the albumin fraction, and presumed to be bilirubin, revealed a well
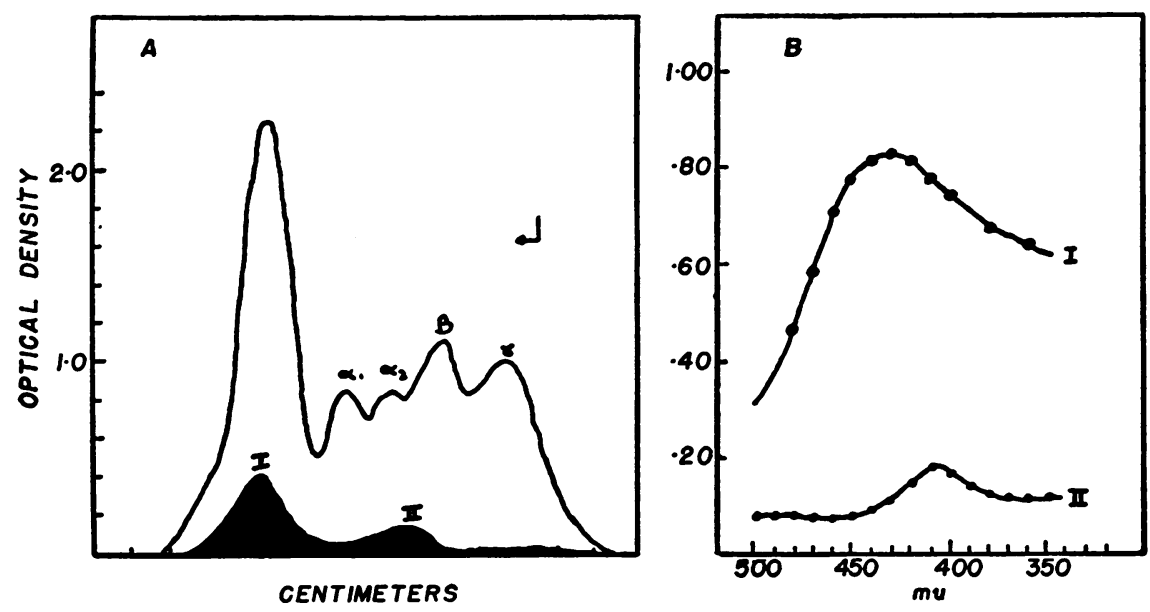

Fig. 1. A. Electrophoretic Pattern of Serum in Obstructive Jaundice Showing Two Pigment Peaks and Their Relationship to the Protein Fractions

Both curves obtained by direct densitometry. Serum bilirubin: direct $25.0 \mathrm{mg}$., total $48.6 \mathrm{mg}$. per $100 \mathrm{ml}$.

B. Absorption Curves of Eluted Pigments illustrated in Figure 1A, Showing Absorption Maximum at $430 \mathrm{~m} \mu$ in Pigment I (Bilirubin) and at $410 \mathrm{~m} \mu$ in Pigment II (Hemoglobin) 
defined absorption maximum at 430 instead of $460 \mathrm{~m} \mu$ (Figure 1B), the value expected for serum bilirubin (18). Errors in instrumentation did not appear to account for this discrepancy, since the accuracy of the wave-length scale of the spectrophotometer employed was verified with the aid of a mercury vapor lamp. Possibly the presence of interfering substances, such as biliverdin, was responsible. However, the bulk of the pigment eluted behaved as bilirubin on diazotization.

The pigment associated with the alpha and beta globulins, and shown to be hemoglobin, had an absorption maximum at $410 \mathrm{~m} \mu$ (Figure 1B), and could, therefore, be readily distinguished from bilirubin.

\section{Spectrophotometric analysis of eluted pigments.}

An attempt was made to demonstrate the presence of bilirubin in the globulin fractions of serum by analyzing the absorption spectrum of each of the eluates of serial transections of the entire elec- trophoretic pattern. The results of two typical experiments on serum with predominantly direct- and indirect-reacting bilirubin, respectively, are illustrated in Figures 2 and 3 . It will be noted that in both instances the only pigment with an absorption maximum at $430 \mathrm{~m} \mu$ was found in the region of the albumin peak. It was not possible to exclude the presence of traces of bilirubin in the globulins, since the analytical procedure employed was insensitive to concentrations below 0.9 micrograms per ml. of eluate, an amount equivalent to $1.80 \mathrm{mg}$. per $100 \mathrm{ml}$. of original serum. However, it was evident that the bulk of the pigment could be accounted for in the albu$\min$ fraction in all cases.

\section{Diazotization of eluted pigments}

To increase the sensitivity and specificity of the method of detecting bilirubin in serial sections of filter-paper electrophoretic patterns, the eluates obtained were subjected to diazotization and ana-
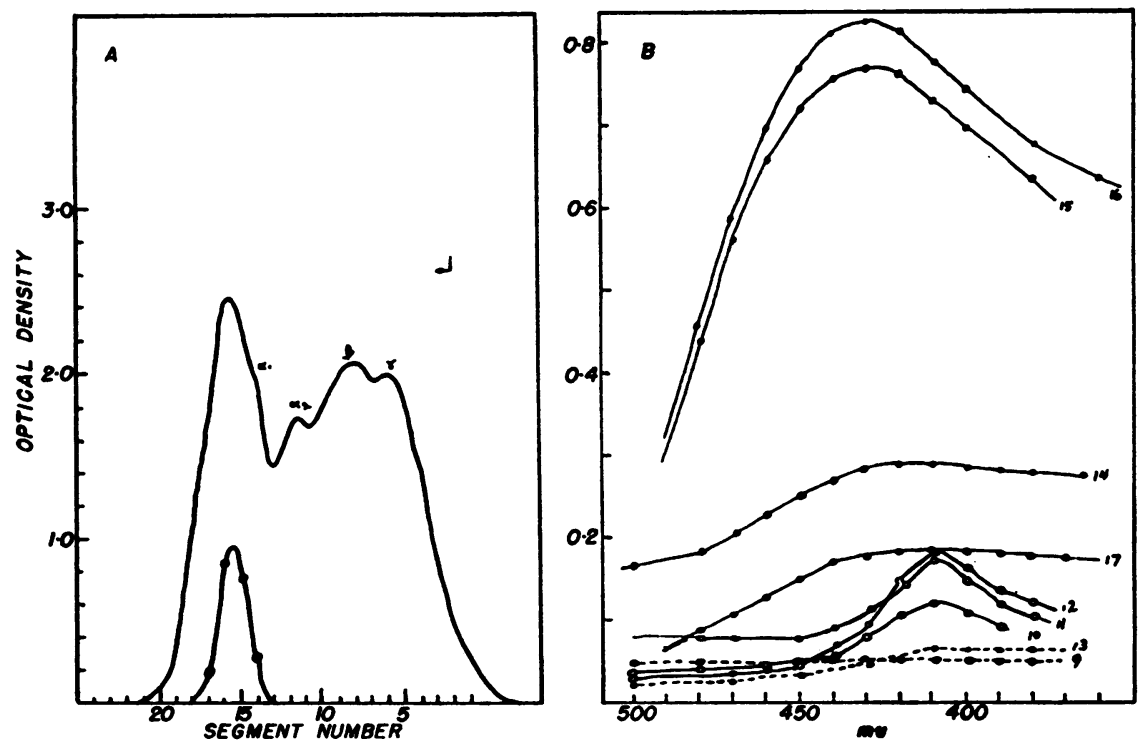

Fig. 2. A. Distribution of Bilirubin (Pigment with an Absorption Maximum at 430 a $\mu$ ) Eluted from Serial Transections of an Electrophoretic Pattern of Seruy in Obstructive Jaundice

Serum bilirubin : direct $8.0 \mathrm{mg}$., total $17.1 \mathrm{mg}$. per $100 \mathrm{ml}$.

B. Absorption Curves of Individual Eluates of 5 m. Segments of the Pattzrn ILLUSTRATEd IN Figure 3A

Note the maximum at $430 \mathrm{~m} \mu$ (bilirubin) in segments 14-17 corresponding to the albumin peak and at $410 \mathrm{~m} \mu$ (hemoglobin) in segments 10-12 corresponding to alpha and beta-globulins. The remaining segments, of which numbers 9 and 13 are representative, showed no maximum. 

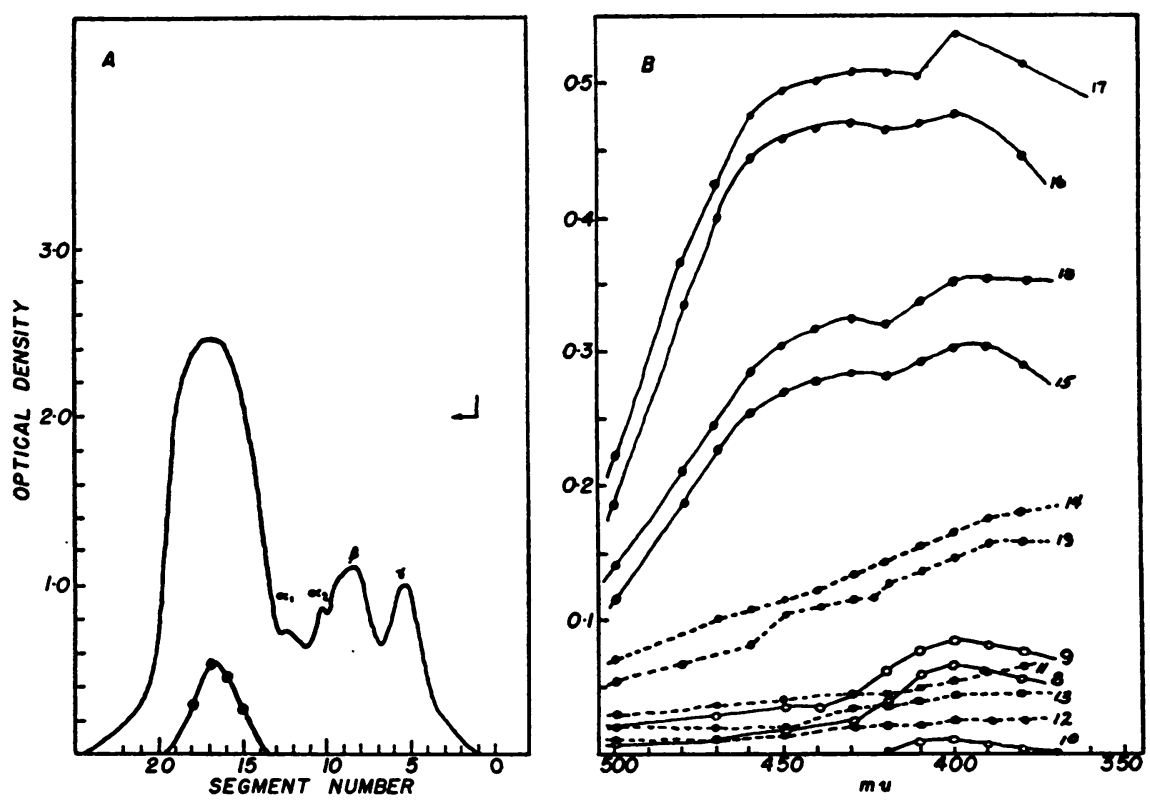

Fig. 3. A. Distribution of Bilirubin (Pigment with an Absorption Maximum at $430 \mathrm{~m} \mu$ ) Eluted from Serial Transections of an Electrophoretic Pattern of Serum in Erythroblastosis Fetalis

Serum bilirubin : direct $0.4 \mathrm{mg}$., total $18.6 \mathrm{mg}$. per $100 \mathrm{ml}$.

B. Absorption Curves of Individual Eluates of 5 mm. Segments of the PatTERN ILlustrated in Figure 4A

Note the maximum at $430 \mathrm{~m} \mu$ (bilirubin) in segments 15-18 corresponding to the albumin peak, and at $410 \mathrm{~m} \mu$ (hemoglobin) in segments 8-10 corresponding to betaglobulin. The remaining eluates, of which only five are illustrated, show nonspecific absorption curves. It will be noted that there is a second maximum at 400 $\mathrm{m} \mu$ in the eluate from segments $15-18$, probably indicating the presence of methemalbumin.

lyzed spectrophotometrically for azobilirubin. The technique used was capable of demonstrating as little as 0.1 microgram of bilirubin per $\mathrm{ml}$. of eluate, a concentration equivalent to $0.24 \mathrm{mg}$. of direct or $0.48 \mathrm{mg}$. of indirect-reacting pigment per $100 \mathrm{ml}$. of original serum. However, it was found that, while this degree of sensitivity could be achieved in recovery experiments with eluates of serum freshly applied to buffer-moistened filterpaper, there was a highly significant loss (average 65 per cent) of diazotizable bilirubin following electrophoresis (Table I), thereby reducing the effective sensitivity of the method to approximately 0.3 microgram per $\mathrm{ml}$. of eluate, a concentration equivalent to $0.72 \mathrm{mg}$. of direct- or 1.44 $\mathrm{mg}$. of indirect-reacting bilirubin per $100 \mathrm{ml}$. of original serum. This apparent loss of bilirubin was probably due to oxidation, since a similar decrease in diazotizable pigment was observed in a control serum applied to moistened filter-paper and exposed to the same atmosphere for a similar length of time. Adsorption of bilirubin in the trail of the proteins during their migration did not appear to be a significant factor, since lengthening the trail by prolonging the electrophoresis did not increase the loss of bilirubin over that of a control serum on moistened paper.

Nine samples of serum were investigated. These were obtained from patients with jaundice, and contained varying proportions of direct- and indirect-reacting bilirubin (Table I). As illustrated by the two representative patterns in Figure 4 , the peaks of both direct- and indirect-reacting bilirubin invariably coincided with that of albumin. In carrying out these experiments non-specific absorption was excluded by analyzing the absorption 
TABLE I

Recovery of serum bilirubin from filter paper following electrophoresis

\begin{tabular}{|c|c|c|c|c|c|}
\hline \multirow{2}{*}{ Type of serum } & \multicolumn{2}{|c|}{$\begin{array}{c}\text { Bilirubin } \\
\text { concentration }\end{array}$} & \multirow{2}{*}{$\begin{array}{l}\text { Bilirubin } \\
\text { applied } \\
\text { to strip† }\end{array}$} & & \\
\hline & Direct* & Total & & \multicolumn{2}{|c|}{ Bilirubin recovered } \\
\hline $\begin{array}{l}\text { Infectious hepatitis } \\
\text { Infectious hepatitis } \\
\text { Laennec's cirrhosis } \\
\text { Laennec's cirrhosis } \\
\text { Laennec's cirrhosis } \\
\text { Laennec's cirrhosis } \\
\text { Obstructive jaundice } \\
\text { Erythroblastosis fetalis } \\
\text { Erythroblastosis fetalis }\end{array}$ & $\begin{array}{c}\text { mg. per cent } \\
11.5 \\
6.3 \\
11.1 \\
12.7 \\
12.7 \\
11.5 \\
13.4 \\
0.4 \\
0.3\end{array}$ & $\begin{array}{l}\text { mg. per cent } \\
26.5 \\
15.8 \\
21.8 \\
28.2 \\
28.2 \\
29.6 \\
28.9 \\
18.6 \\
18.4\end{array}$ & $\begin{array}{l}m c g . \\
21.2 \\
12.6 \\
17.4 \\
22.6 \\
22.6 \\
23.7 \\
23.1 \\
14.9 \\
14.7\end{array}$ & $\begin{aligned} m c g . \\
19.9 \\
4.7 \\
7.0 \\
5.7 \\
4.8 \\
7.8 \\
12.7 \\
4.7 \\
4.9\end{aligned}$ & $\begin{array}{c}\text { per cent } \\
90 \ddagger \\
37 \\
40 \\
25 \\
21 \\
33 \\
55 \\
32 \\
33\end{array}$ \\
\hline
\end{tabular}

* Prompt direct-reacting (one-minute) fraction.

† Amount remaining on the filter-paper strip following removal of an $8 \mathrm{~mm}$. longitudinal segment for protein analysis; original width of strip $40 \mathrm{~mm}$., volume of serum applied $0.1 \mathrm{ml}$.

$\ddagger$ This value was omitted in calculating the average recovery ( 34.5 per cent), since it was not possible to achieve this degree of recovery in subsequent experiments.

spectrum of each eluate. Only those pigments showing a well defined maximum at $540 \mathrm{~m} \mu$ following diazotization were considered bilirubin.

\section{Experiments with globin}

The concept that the type of van den Bergh reaction in serum depends on whether bilirubin is bound to albumin or globin is based almost en- tirely on the evidence presented by Fiessinger, Gaydos, and Polonovski $(9,10)$. These investigators have reported that neutralized solutions of bilirubin react directly in the presence of serum albumin and indirectly in the presence of globin, and that it is possible to convert the direct-reacting type to the indirect by incubating serum at ice-box temperature in the presence of globin, a change



Fig. 4. A. Distribution of Direct-Reacting (•---•) and Total (•Bilirubin in Eluates from Serial Transections of an Electrophoretic Pattern of Serum in Laennec's Cirrhosis

The indirect-reacting fraction of bilirubin is represented by the area between the two pigment curves beneath the albumin peak. Serum bilirubin: direct 12.7, total 28.2 mg. per $100 \mathrm{ml}$.

B. Distribution of Indirect-Reacting Bilirubin (·-•) in Eluates from Serial Transections of an Electrophoretic Pattern of Serum in ErythroblasTOSIS Fetalis

No direct-reacting pigment could be demonstrated. Serum bilirubin: direct 0.4 , total $18.6 \mathrm{mg}$. per $100 \mathrm{ml}$. 
presumably due to a shift of pigment from albumin to globin.

In a preliminary experiment, based on the technique described by Fiessinger, Gaydos, and Polonovski (9) the qualitative van den Bergh reaction of bilirubin-protein mixtures was investigated. Bilirubin was dissolved in $0.01 \mathrm{~N} \mathrm{NaOH}$ at a concentration of $40 \mathrm{mg}$. per $100 \mathrm{ml}$. and added in amounts ranging from 0.2 to $0.6 \mathrm{ml}$. to $2-\mathrm{ml}$. aliquots of 0.35 per cent albumin ${ }^{4}$ or globin. ${ }^{5}$ With the aid of a glass electrode the mixtures were then brought to a $\mathrm{pH}$ of 7.0 and allowed to stand for one hour, following which $0.5 \mathrm{ml}$. of freshly prepared diazo reagent was added to each tube. An indirect reaction was obtained in all tubes, indicating that the reactivity of bilirubin was not dependent on the nature of the protein with which it was associated.

To characterize the behavior of these bilirubinprotein mixtures more precisely, their diazotization reaction curves were then investigated spectrophotometrically. The solutions tested were prepared and analyzed as follows: (a) to 8-ml. aliquots of 0.35 per cent albumin and globin were added $2-\mathrm{ml}$. portions of a $10 \mathrm{mg}$. per cent solution of bilirubin, (b) the mixtures were then brought to a $\mathrm{pH}$ of 7.0 and allowed to stand for one hour; to maintain the same concentrations of bilirubin and protein in both mixtures their volumes were equalized with water following neutralization, (c) two 3-ml. aliquots of each mixture were then transferred to $1-\mathrm{cm}$. cuvettes to which were added 0.6ml. portions of freshly prepared diazo reagent and blank, respectively, (d) optical density was then measured at frequent intervals for a period of 30 minutes in a Beckman DU spectrophotometer at a wave-length of $540 \mathrm{~m} \mu$, (e) at the end of this period an equal volume of absolute methanol was added to each cuvette and the optical density measured as before. The final concentrations of protein and bilirubin before diazotization were 223 and $1.82 \mathrm{mg}$. per $100 \mathrm{ml}$., respectively. A control solution of bilirubin without protein was analyzed simultaneously. It had a slightly lower concentra-

\footnotetext{
4 Crystallized human serum albumin obtained from the Harvard University Laboratory of Physical Chemistry, through the courtesy of Dr. J. L. Oncley.

5 Prepared in the authors' laboratory by the method of Anson and Mirsky (19).
}



Fig. 5. Diazotization Reaction Curves of Neutralized Solutions of Bilirubin in the Presence of Globin AND Albumin

tion of bilirubin, $1.43 \mathrm{mg}$. per $100 \mathrm{ml}$., since it required a larger volume of acid for neutralization.

The diazotization curves obtained in this experiment are illustrated in Figure 5 . It will be observed that in all three solutions less than 10 per cent of the bilirubin reacted directly during the first minute, and less than 15 per cent in 30 minutes, behavior characteristic of indirect-reacting serum (14). When alcohol was added, there was a prompt increase in the rate of diazotization in all tubes. However, at the end of 30 minutes there was a marked difference in the amount of azobilirubin recovered in each of the solutions. While all of the pigment reacted in the albumin mixture, only 70 per cent reacted in the control solution and less than 35 per cent in the globin mixture. The loss of reactivity in the control solution was undoubtedly due to the oxidation of bilirubin, an effect which was inhibited by combining the pigment with albumin (20). The fact that even less azobilirubin was recovered in the presence of globin than in the control solution indicated that globin was not only a less effective anti-oxidant than albumin, but that it actually increased the loss of diazotizable pigment. A clue to the mechanism involved was afforded by the observation that the bilirubin-globin solution became slightly turbid when it was neutralized. This suggested the possibility that the mixture had partially precipitated when the $\mathrm{pH}$ was brought 
to 7.0, a suspicion that was confirmed when the experiment was repeated using higher concentrations of protein and bilirubin.

The solubility and bilirubin-binding capacity of globin at the normal $\mathrm{pH}$ of blood were then determined, since it seemed possible from the preceding experiments that normal serum might be incapable of holding sufficient bilirubin-globin in solution to account for the amount of indirectreacting bilirubin found in many hemolytic states. A modification of Martin's method (21) was used to obtain these data. This entailed the dialysis of a 0.365 per cent globin solution against an excess

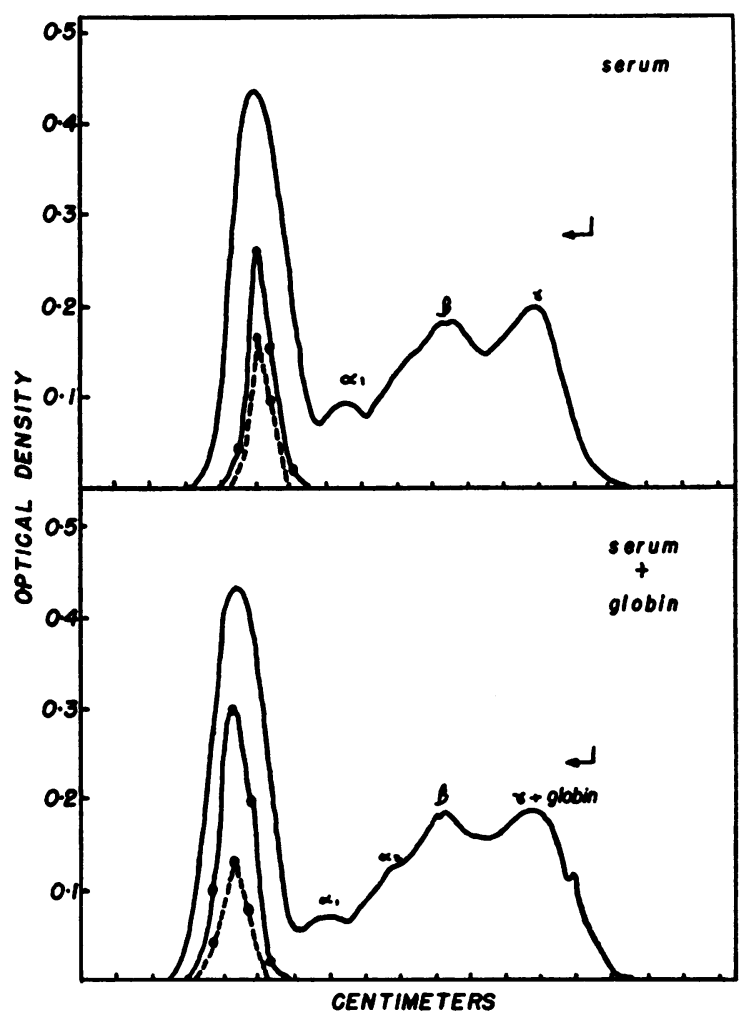

Fig. 6. Effect of Incubating Direct-Reacting Serum with Globin at $10^{\circ} \mathrm{C}$ for 18 Hours

The upper panel shows the relationship of the eluted pigments to the electrophoretically separated proteins of $0.075 \mathrm{ml}$. of serum containing $4.5 \mathrm{mg}$. of direct-reacting and $10.8 \mathrm{mg}$. of total bilirubin per $100 \mathrm{ml}$. It will be noted that both the direct $(\cdot---\cdot)$ and indirect-reacting (- - ) bilirubin are confined to the albumin fraction. The lower pattern, which was obtained with $0.150 \mathrm{ml}$. of an equal mixture of the same serum and 3.5 per cent globin following incubation, shows essentially the same ratio of direct- to indirect-reacting bilirubin and the absence of any shift of pigment to the globin peak.

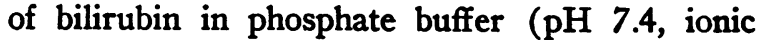
strength 0.1) containing ascorbic acid, and the determination of its bilirubin and protein content following a period of equilibration at $10^{\circ} \mathrm{C}$. A control experiment, in which the cellophane sac contained buffer instead of globin solution, was carried out simultaneously. It was assumed that equilibrium had been reached when the bilirubin concentrations were identical on both sides of the membrane in the control experiment. This occurred in approximately 48 hours, at which time the buffer in both compartments of the control chamber had a bilirubin concentration of $0.40 \mathrm{mg}$. per $100 \mathrm{ml}$., based on direct measurements of absorption at $430 \mathrm{~m} \mu$ in a Beckman DU spectrophotometer. At the same time, the globin mixture, which was now turbid due to precipitation of protein, was found to have a bilirubin content, after centrifugation, of $1.29 \mathrm{mg}$. per $100 \mathrm{ml}$. Since the concentration in the surrounding buffer was similar to that of the control, $0.37 \mathrm{mg}$. per $100 \mathrm{ml}$., it was assumed that $0.92 \mathrm{mg}$. of bilirubin per 100 $\mathrm{ml}$. had been bound by the globin remaining in solution. By the Kjeldahl method the latter was found to be present in a concentration of $0.205 \mathrm{gm}$. per $100 \mathrm{ml}$., which was taken to be the approximate solubility of globin at $\mathrm{pH} 7.4$. If these estimates of globin solubility and bilirubin-binding capacity are valid a bilirubin-globin complex could hardly account for more than $1 \mathrm{mg}$. of indirectreacting bilirubin per $100 \mathrm{ml}$. at the normal $\mathrm{pH}$ of serum.

On electrophoretic analysis the mobility of globin, which approximated that of a gamma globulin, differed from that of either direct- or indirect-reacting serum bilirubin. Moreover, when globin was added to an icteric serum containing a high proportion of direct-reacting bilirubin and was incubated at $10^{\circ} \mathrm{C}$ for 18 hours, there was no electrophoretic evidence of a shift of pigment to the globin peak, nor any increase in the relative concentration of indirect-reacting bilirubin (Figure 6), findings at variance with those reported by Fiessinger, Gaydos, and Polonovski (9).

The data presented strongly suggest that none of the bilirubin in serum is bound to globin. However, the evidence cannot be regarded as conclusive, since, as in all experiments involving the isolation and, particularly, the chemical manip- 
ulation of globin, the question of denaturation arises. In both the present experiments and those described by Fiessinger, Gaydos, and Polonovski (9) globin was prepared and purified by the method of Anson and Mirsky (19). Although this material is thought to be undenatured, particularly since it can be recombined with heme to form hemoglobin (19) it is noteworthy that it has a molecular weight only one-fourth that estimated for the protein moiety of hemoglobin (22) and that the physical properties of the hemoglobin derived from it differ slightly from those of the natural product $(23,24)$. Moreover, in the present experiments the use of alkaline solutions of bilirubin may have denatured the globin further.

\section{Experiments with alpha $a_{1}$-globulin}

Since the alpha ${ }_{1}$-globulin of Fraction V-1 was found by Cohn (12) to give an indirect van den Bergh reaction, and was shown by Martin (21) to be capable of binding additional bilirubin, the possibility that the bilirubin in predominantly indirect-reacting serum was associated with this fraction was investigated. When Fraction $\mathrm{V}-1^{\circ}$ was added to a serum from a patient with hemolytic jaundice the expected increase in alpha ${ }_{1}$ globulin was clearly discernible in the electrophoretic pattern; however, the peak obtained did not coincide with that of bilirubin. In addition, it was found that albumin had a greater affinity for bilirubin than the alpha ${ }_{1}$-globulin of Fraction V-1. Thus, by means of electrophoresis it could be shown that both proteins were capable of combining with bilirubin in vitro, but that when an alkaline solution of bilirubin was added to a mixture of the proteins, the pigment migrated with the albumin exclusively, although undetected traces may have been present in alpha ${ }_{1}$-globulin peak. It is reasonable to suppose, therefore, that there is a similar preferential binding of bilirubin by albu$\min$ in vivo. Moreover, on the basis of its known concentration of 0.05 per cent of plasma (12) and its bilirubin-binding capacity of $12 \mathrm{mg}$. per $\mathrm{gm}$. (21), it was estimated that an alpha ${ }_{1}$-globulin complex could not account for more than $0.05 \mathrm{mg}$. of indirect-reacting bilirubin per $100 \mathrm{ml}$. of serum.

- Obtained from the Harvard University Laboratory of Physical Chemistry through the courtesy of Dr. J. L. Oncley.

\section{Ammonium sulfate fractionation of serum bilirubin}

According to Najjar and Childs $(11,13)$ the ammonium sulfate fractionation patterns of serum bilirubin indicate that the direct-reacting type is bound to albumin, and the indirect to a globulin. However, they attach no importance to this difference insofar as the van den Bergh reaction is concerned, since they have found that the pigments retain their characteristic behavior on diazotization following their separation from protein.

Since Najjar's observations on the proteinlinkages of bilirubin in serum were not in accord with those based on electrophoresis, an attempt was made to confirm the reported difference in the ammonium sulfate fractionation patterns of direct- and indirect-reacting bilirubin. The technique employed was virtually identical with that described by Najjar and Childs (13). Fourtenths of a ml. of serum was pipetted into each of 12 celluloid centrifuge tubes. Sufficient water, bromphenol blue and saturated ammonium sulfate were then added to yield ammonium sulfate concentrations ranging from 32 to 72 per cent saturation, and a bromphenol blue concentration of $0.04 \mathrm{mg}$. per ml. of serum in a total volume of $10 \mathrm{ml}$. The salt was added dropwise with stirring to ensure adequate mixing. The samples were then stored in the refrigerator at $5^{\circ} \mathrm{C}$ for one hour, following which they were centrifuged for 30 minutes at 40,000 RPM.

The sediment in each tube was redissolved in $5 \mathrm{ml}$. of saline and analyzed for bilirubin and bromphenol blue by measuring its absorption at $460 \mathrm{~m} \mu$ and $605 \mathrm{~m} \mu$, respectively, in a Beckman DU spectrophotometer. Corresponding concentrations of ammonium sulfate and water served as blanks. Due to the development of turbidity, it was not possible to check the results by diazotization, as reported by Najjar and Childs (13). Bilirubin determinations were also carried out on the supernatants, which revealed that excellent recoveries of total pigment were being achieved.

Seven serum samples were studied, four of the direct-reacting type from patients with various forms of obstructive or hepatocellular jaundice, and three of the indirect type from infants with erythroblastosis fetalis. In all instances the serum was virtually hemoglobin-free. Nevertheless, in analyzing the mixtures for bilirubin a correction 

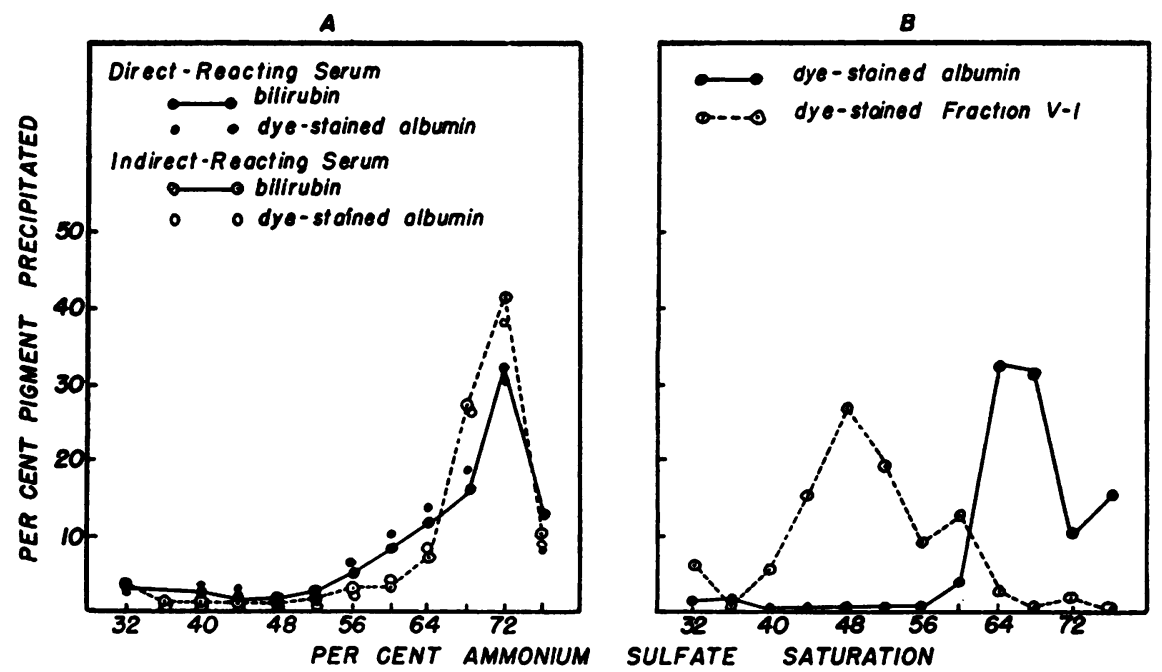

Fig. 7. A. Ammonium Sulfate Fractionation Patterns of Bilirubin and Added Bromphenol Blue in Direct- and Indirect-Reacting Serum

The former contained $19.7 \mathrm{mg}$. of bilirubin per $100 \mathrm{ml}$., of which $10.6 \mathrm{mg}$. reacted directly, the latter $22.1 \mathrm{mg}$. per $100 \mathrm{ml}$., of which $0.6 \mathrm{mg}$. reacted directly.

B. Ammonium Sulfate Fractionation Patterns of Bromphenol Blue in 4 Per Cent Solutions of Serum Albumin and Cohn's Fraction V-1

for hemoglobin was made, as suggested by Najjar (11) by using the following formula:

True absorption at $460 \mathrm{~m} \mu=\mathrm{A}_{460}$

$$
-\frac{A_{420}-\left(A_{460} \times 0.86\right)}{4}
$$

where $A_{460}=$ absorption of bilirubin at $460 \mathrm{~m} \mu$, and $\mathrm{A}_{\mathbf{4 2 0}}=$ absorption of bilirubin at $420 \mathrm{~m} \mu$.

In all but one instance a direct- and an indirectreacting serum were analyzed simultaneously to maintain identical conditions. It was found, in contrast to the observations of Najjar and Childs (13), that the fractionation pattern of precipitated bilirubin invariably coincided with that of bromphenol blue-labelled albumin, both in direct- and indirect-reacting serum (Figure 7A). As a further check on the apparent similarity of the precipitation patterns of direct- and indirect-reacting bilirubin to that of albumin, ammonium sulfate fractionation was carried out on bromphenol bluestained solutions of human serum albumin ${ }^{7}$ and Cohn's fraction V-1. This appeared to be an essential control, since it was found that unbound dye could always be detected in the presumably pro-

Talt-poor concentrated human serum albumin obtained from the American Red Cross through the courtesy of Dr. S. T. Gibson. tein-free supernatant at 76 per cent ammonium sulfate saturation, even when the lowest concentration of dye recommended by Najjar and Childs (13) was used, indicating that an excess was always available for staining of globulin. Fraction $\mathrm{V}-1$ was selected for testing since Najjar (11) had suggested that indirect bilirubin might be associated with an alpha-globulin. As can be seen in Figure 7B, the fractionation pattern of dyelabelled albumin approximated that of proteinbound bilirubin in both direct- and indirect-reacting serum, and that the pattern of dye-labelled Fraction V-1 resembled neither.

No explanation can be offered for the discrepancy between the results reported by Najjar and Childs (13) and those obtained in this laboratory. However, the latter would appear to be more consistent with the other evidence presented indicating that bilirubin is bound to albumin in both types of serum.

\section{Effect of $p H$ change on the electrophoretic mo- bility of serum bilirubin}

If different proteins bind the two types of bilirubin in serum, it must be assumed that their electrophoretic mobilities are identical, as in the case of the pigments. While it is possible for hetero- 
geneous proteins to migrate at the same rate under certain conditions, it is highly improbable that they will do so over a wide range of $\mathrm{pH}$ if they differ as markedly in amino acid composition as albumin and globin (25). For that reason the electrophoretic patterns of sera containing predominantly direct- and indirect-reacting bilirubin, respectively; were compared in buffers ranging in $\mathrm{pH}$ from 2.0 to 9.0. Both samples were run simultaneously in the same chamber to ensure identical conditions. The buffers, which had an ionic strength of 0.1 , were made up of glycine- $\mathrm{HCl}$ for $\mathrm{pH} 2.0$ and 3.0, sodium acetate-acetic acid for $\mathrm{pH} 4.0$ and 5.0, $\mathrm{Na}_{2} \mathrm{HPO}_{4}-\mathrm{NaH}_{2} \mathrm{PO}_{4}$ for $\mathrm{pH} 6.0$ and 7.0, and sodium veronal- $\mathrm{HCl}$ for $\mathrm{pH} 8.0$ and 9.0. In a duplicate experiment the ionic strength of the buffer salt was kept at 0.02 and brought to 0.1 with sodium chloride, as recommended by Miller and Golder (26). This modification did not appear to alter the mobilities of either protein or bilirubin. The position of the albumin peaks indicated in each of the patterns illustrated in Figure 8 was checked against that of pure serum albumin electrophoresed under the same conditions. The results of three experiments with different pairs of sera were virtually identical.

As is evident in Figure 8, the mobility of bilirubin was identical in both types of serum at all levels of $\mathrm{pH}$ except 5.0. Between $\mathrm{pH} 6.0$ and 9.0 the two pigments migrated as well-defined bands which coincided with their respective albumin peaks. However, at $\mathrm{pH} 5.0$ a marked difference was observed. In the direct-reacting serum the bilirubin was concentrated in the albumin fraction, but could also be detected in small amounts in the trail of the globulins. In contrast, the pigment in the indirect-reacting serum was confined to a narrow band close to the anodal side of the starting line, and had the granular appearance of a precipitate. Since the serum had been applied at the cathodal end of the strip, it appeared likely that the movement of the indirect-reacting pigment was due not to its linkage with a non-albuminous protein, but rather to capillarity and the siphoning effect known to occur as buffer evaporates from the center of the filter-paper strip during electrophoresis (16). In order to determine whether the pigments were bound to protein, duplicate sera were electrophoresed for 16 hours, following which one of the strips was removed for staining, while the other was subjected to an additional 7-hour period of electrophoresis with the poles reversed, which served to return the proteins toward their line of origin. It was found that the pigment in the indirect-reacting serum remained stationary despite the backward movement of the proteins, indicating that it was no longer linked to protein, while the pigment in the direct-reacting serum continued to migrate with the albumin peak indicating an intact bond. By streaking the serum over the center of the strip instead of at its cathodal end, it was possible to reduce the siphoning effect previously mentioned. As a result, the indirect-reacting bilirubin no longer migrated toward the anode, but appeared as a broad band



Fig. 8. Effect of PH on the Relattve Electrophoretic Mobilities of Bilirubin (Shaded Areas) and Albumin (Solid Circles) in Direct- and IndirectReacting Serum

The former was obtained from a patient with cirrhosis and contained $25.5 \mathrm{mg}$. of bilirubin per $100 \mathrm{ml}$., of which $11.7 \mathrm{mg}$. reacted directly; the latter was obtained from an infant with erythroblastosis fetalis and contained $10.4 \mathrm{mg}$. of bilirubin per $100 \mathrm{ml}$., of which $0.1 \mathrm{mg}$. reacted directly. 
centered over the line of application. In contrast, the bulk of the direct-reacting bilirubin was still evident in the albumin fraction as it moved toward the anode; however, the previously noted pigmenttrail in the globulin range was more prominent. These observations suggested that the bilirubinalbumin complex of serum was split at a $\mathrm{pH}$ of 5.0, releasing relatively insoluble free bilirubin, and that the cleavage was more complete in the case of indirect-reacting serum. Conceivably, the unbound pigment found in the globulin trail of the direct-reacting serum represented the indirectreacting fraction present originally, while the pigment bound to albumin was all of the direct-reacting type.

At levels of $\mathrm{pH}$ between 2.0 and 4.0 it was found that the separation of bilirubin and albumin was complete in both types of serum (Figure 8 ). Reversal of the migration and shifting the line of serum application were again used to exclude the possibility that bilirubin was bound to a non-albuminous protein. At $\mathrm{pH} 2.0$ and 3.0 there was distinct precipitation to the cathodal side of the starting line, not only of bilirubin but also of protein. Beyond this point both the protein and pigment were arranged in a pattern of irregular longitudinal streaks.

It is clear from these experiments that the electrophoretic mobilities of direct- and indirect-reacting bilirubin in serum are identical with that of albumin over a $\mathrm{pH}$ range of 6.0 to 9.0. Since albumin and globin differ markedly with respect to their isoelectric points, which lie at $\mathrm{pH} 4.4$ (27) and 7.5 (28), respectively, the two proteins could hardly migrate as a single peak at $\mathrm{pH} 6.0$ and 7.0. It must be concluded, therefore, that the bulk of the indirect-reacting bilirubin of icteric serum is not bound to globin.

The observation that both types of bilirubin separate from their albumin complexes when the


Fig. 9. A. Solubility of Pure Bilirubin (Hoffman-LaRoche) in Varying Concentrations of Chloroform in Methanol

An excess of bilirubin was shaken for one-half hour with each of the mixtures in a sealed nitrogen-filled bottle. The concentration of pigment was determined spectrophotometrically at $450 \mathrm{~m} \mu$ following centrifugation and filtration. Values shown are averages of triplicate determinations.

B. Diazotization Reaction Curves of Bilirubin in Increasing Concentrations of Chloroform in Methanol Showing the Direct Relationship between Speed of Diazotization and Chloroform Concentration

All reaction mixtures contained $10 \mathrm{ml}$. of water and $0.4 \mathrm{mg}$. of bilirubin per $100 \mathrm{ml}$. The remainder was made up of varying proportions of methanol and chloroform as indicated. Values shown are averages of triplicate determinations. 
SERUM BILIRUBIN-PROTEIN LINRAGES

TABLE II

Recovery of direct- and indirect-reacting bilirubin * in mixtures of serum of differing bilirubin content



- Determined by a modification (14) of the Malloy-Evelyn method (15) adapted to the Beckman DU spectrophotometer.

$\dagger$ Values expected if there were simple summation of two distinct forms of bilirubin.

$\mathrm{pH}$ falls below 5.0 is of considerable interest, since diazotization is usually carried out at a $\mathrm{pH}$ of 2.0 to 4.0, depending on the technique employed. Obviously, then, the direct and indirect reactions cannot be related to differences in protein linkage. An alternative possibility that merits consideration is that the type of reaction depends on the solubility of unbound bilirubin in an acid medium. At the $\mathrm{pH}$ of the van den Bergh reaction the pigment is known to be relatively insoluble in water (29) and, hence, incapable of diazotization (30). However, in the case of serumdiazo mixtures significant solution must occur, since a direct-reacting fraction of pigment can be detected in all sera $(1,14)$. It is conceivable, therefore, that the percentage of bilirubin that reacts directly is a function of solubility, dependent either on differences in the solvent properties of serum itself, or on the presence of variable proportions of two pigments with different solubilities at low $\mathrm{pH}$. Accordingly, substances like alcohol and caffeine might facilitate the diazotization of indirect-reacting bilirubin by increasing its solubility.
In support of this hypothesis it was possible to demonstrate a relationship between the solubility of bilirubin and its rate of diazotization in several experimental systems. However, it was not possible to do so in the case of serum. Thus, it was found that in chloroform-methanol mixtures both the solubility and rate of diazotization of bilirubin increased as the proportion of chloroform in the system rose (Figure 9). A similar relationship could also be established in an aqueous system in which the $\mathrm{pH}$ was varied. The possibility was considered that the solubility of bilirubin in directreacting serum might be enhanced by the presence of the hypothetical catalyst described by Cantarow (31). However, when sera containing different proportions of direct- and indirect-reacting bilirubin were mixed, the final concentrations observed were those predicted for the simple summation of two pigments (Table II), and did not show the relative increase in the direct-reacting fraction reported by Cantarow (31). Similarly, when ultrafiltrates of normal and strongly directreacting serum were compared with respect to their capacity to enhance the diazotization rate of 
a slow-reacting alkaline solution of bilirubin in albumin no difference was observed.

Although there is no evidence to support the hypothesis that the ratio of direct- to indirectreacting bilirubin in serum depends on the solvent properties of serum itself, it is difficult to exclude the possibility that the ratio is related to the presence of varying proportions of two pigments with different solubilities. Indeed, the recent observations of Cole and Lathe (32), indicating that the two pigments can be separated by reverse phase chromatography, and that the direct-reacting type is more soluble in water, are consistent with this interpretation.

Najjar and Childs (33) have found that, when serum is brought to a $\mathrm{pH}$ of 5.0 , ether will extract most indirect-reacting pigment, but only 2 per cent of the direct-reacting type, a phenomenon consistent with our observation that the former separates from its albumin complex at $\mathrm{pH} 5.0$, and the latter at $\mathrm{pH} 4.0$. It is also known that the two pigments differ with respect to their solubility in organic solvents at the normal $\mathrm{pH}$ of serum (6, 34). These observations suggest that the linkage between bilirubin and albumin differs in the two types of serum, and are also consistent with the concept that there is a subtle difference in the structure of the two pigments.

\section{SUM MARY}

By means of filter-paper electrophoresis it has been shown that most, if not all, of the bilirubin in serum is bound to albumin, irrespective of its behavior in the van den Bergh reaction. While it is not possible by this technique to exclude the presence of small amounts of pigment in the alpha ${ }_{1}$ globulin of Cohn's Fraction V-1, it has been calculated, from what is known about its concentration in plasma and its bilirubin-binding capacity, that it cannot account for more than $0.05 \mathrm{mg}$. of bound pigment per $100 \mathrm{ml}$. of serum.

Several lines of evidence have been presented to show that indirect-reacting serum bilirubin is not a globin complex. These include the demonstration that (a) the electrophoretic mobility of native globin differs from that of serum bilirubin, (b) the direct- and indirect-reacting pigments cannot be separated electrophoretically at $\mathrm{pH}$ 6.0 , a level at which albumin and globin migrate toward opposite poles, and (c) the solubility and bilirubin-binding capacity of globin are so low at the normal $\mathrm{pH}$ of the blood that a globin complex, if present, could not account for more than 1.0 mg. of bound pigment per $100 \mathrm{ml}$.

Attempts to distinguish between the two types of pigment in serum on the basis of their ammonium sulfate fractionation patterns have been unsuccessful, both patterns invariably coinciding with that of albumin.

It has been found that both types of bilirubin in serum remain firmly bound to albumin at levels of $\mathrm{pH}$ between 6.0 and 9.0, and separate at levels below 5.0. Only at $\mathrm{pH} 5.0$ has a difference been observed, the separation of pigment from protein being relatively complete in the indirect-reacting type and partial in the direct-reacting, suggesting that the protein-linkages of the two pigments differ. Since the van den Bergh reaction is usually carried out at a $\mathrm{pH}$ of 2.0 to 4.0 , it must be assumed that both types of bilirubin are in an unbound state when they react with the diazo reagent.

The implications of these observations have been discussed and the possibility has been considered that the variable behavior of bilirubin on diazotization may be related to differences in its solubility in an acid medium. Recent chromatographic evidence, suggesting that the two pigments differ with respect to their chemical structure and solubility in water, appears to be consistent with this hypothesis.

It is concluded that (a) the bulk of bilirubin in serum is bound to albumin, irrespective of its behavior in the van den Bergh reaction, (b) there is no evidence that, in the breakdown of hemoglobin, globin remains attached to its prosthetic group to yield indirect-reacting bilirubin, (c) the two types of van den Bergh reaction are not related to differences in bilirubin-protein linkage, and (d) the action of alcohol in facilitating the diazotization of indirect-reacting bilirubin does not depend on the cleavage of a pigment-protein complex.

\section{REFERENCES}

1. Watson, C. J., Some newer concepts of the natural derivatives of hemoglobin. Blood, 1946, 1, 99.

2. Young, L. E., Current concepts of jaundice, with particular reference to hepatitis. New England J. Med., 1947, 237, 225, 261. 
3. Levi-Crailsheim, P., Theoretische und experimentelle Untersuchungen über Bilirubin und Fibrinogen im Blut. Ztschr. f. d. ges. exper. Med., 1923, 32, 468.

4. Gregory, R. L., and Andersch, M., The filtrability of bilirubin in obstructive jaundice. J. Lab. \& Clin. Med., 1937, 22, 1111.

5. Snapper, I., and Bendien, W. M., On the physicochemical condition of the bilirubin in the blood serum and urine. Acta med. Scandinav., 1938, 98, 77.

6. Coolidge, T. B., Chemistry of the van den Bergh reaction. J. Biol. Chem., 1940, 132, 119.

7. Pedersen, K. O., and Waldenström, J., Studien über das Bilirubin in Blut und Galle mit Hilfe von Elektrophorese und Ultrazentrifugierung. Ztschr. f. physiol. Chem., 1937, 245, 152.

8. Gray, C. H., and Kekwick, R. A., Bilirubin-serum protein complexes and the van den Bergh reaction. Nature, 1948, 161, 274.

9. Fiessinger, N., Gaydos, A., and Polonovski, M., Le role de la globine dans la réaction indirecte de diazotation de la bilirubine. Compt. rend. Soc. de biol., 1941, 135, 1572.

10. Fiessinger, N., Gajdos, A., and Polonovski, M., Sur la bilirubinoglobine et la globine libre du plasma sanguin. Compt. rend. Soc. de biol., 1942, 136, 714.

11. Najjar, V. A., The metabolism of bilirubin. Pediatrics, 1952, 10, 1.

12. Cohn, E. J., The chemical specificity of the interaction of diverse human plasma proteins. Blood, 1948, 3, 471.

13. Najjar, V. A., and Childs, B., The crystallization and properties of serum bilirubin. J. Biol. Chem., 1953, 204, 359.

14. Klatskin, G., and Drill, V. A., The significance of the "one-minutes" (prompt direct reacting) bilirubin in serum. J. Clin. Invest., 1950, 29, 660.

15. Malloy, H. T., and Evelyn, K. A., The determination of bilirubin with the photoelectric colorimeter. J. Biol. Chem., 1937, 119, 481.

16. Grassmann, W., and Hannig, K., Ein quantitatives Verfahren zur Analyse der Serumproteine durch Papierelektrophorese. Ztschr. f. physiol. Chem., 1952, 290, 1.

17. Kirk, P. L., Rosenfels, R. S., and Hanahan, D. J., Capillary absorption cells in spectrophotometry. Indust. \& Engin. Chem., (Anal. Ed.), 1947, 19, 355.

18. Heilmeyer, L., Spectrophotometry in Medicine (translated by A. Jordan). London, A. Hilger, Ltd., 1943.
19. Anson, M. L., and Mirsky, A. E., Protein coagulation and its reversal. The preparation of insoluble globin, soluble globin and heme. J. Gen. Physiol., 1930, 13, 469.

20. Barac, G., and Gernay, J. M., Recherches sur la cénapse albumino-bilirubinique. Bull. Soc. chim. biol., 1949, 31, 128.

21. Martin, N. H., Preparation and properties of serum and plasma proteins. XXI. Interactions with bilirubin. J. Am. Chem. Soc., 1949, 71, 1230.

22. Reiner, L., Moore, D. H., Lang, E. H., and Green, M., Electrophoretic components of globin. J. Biol. Chem., 1942, 146, 583.

23. Hill, R., and Holden, H. F., The preparation and some properties of the globin of oxyhaemoglobin. Biochem. J., 1926, 20, 1326.

24. Gralén, N., The splitting of haemoglobin by acids. Biochem. J., 1939, 33, 1907.

25. Fruton, J. S., Personal communication.

26. Miller, G. L., and Golder, R. H., Buffers of $\mathrm{pH} 2$ to 12 for use in electrophoresis. Arch. Biochem., $1950,29,420$.

27. Alberty, R. A., A study of the variation of the average isoelectric points of several plasma proteins with ionic strength. J. Phys. \& Colloid Chem., 1949, 53, 114.

28. Munro, M. P., and Munro, F. L., The electrophoretic properties of globin from various species. J. Biol. Chem., 1943, 150, 427.

29. Kerppola, W., and Leikola, E., Zur Chemie des Bilirubins. I. Das Verhalten des Bilirubins zu verschiedenen Lösungsmitteln bei wechselnder Wasserstoffionenkonzentration. Skandinav. Arch. f. Physiol., 1929, 54, 120.

30. Kilchling, H., and Kuhn, H. A., Uber die Diazoreaktion eiweissfreier Bilirubinlösungen. Ztschr. f. d. ges exper. Med., 1951, 117, 481.

31. Cantarow, A., The direct van den Bergh reaction in mixtures of normal and jaundiced serum. Am. J. Digest. Dis., 1944, 11, 144.

32. Cole, P. G., and Lathe, G. H., The separation of serum pigments giving the direct and indirect van den Bergh reaction. J. Clin. Path., 1953, 6, 99.

33. Najjar, V. A., and Childs, B., The crystallization of "direct" and "indirect" bilirubin from human serum and their respective properties. J. Clin. Invest., 1951, 30, 663.

34. Roberts, W. M., Observations on the nature of the van den Bergh reaction. Brit. J. Exper. Path., 1928, 9, 107. 